\title{
NUMERICAL STUDIES OF FLUID FLOW IN FLAT, NARROW-GAP CHANNELS SIMULATING PLATE HEAT EXCHANGER ${ }^{1}$
}

\author{
Joanna Piepiórka-Stepuk*, Marek Jakubowski \\ Koszalin University of Technology Department of Mechanical Engineering, Division of Food \\ Industry Processes and Facilities, ul. Racławicka 15-17, 75-620 Koszalin, Poland
}

\begin{abstract}
The aim of this work was to present the numerical simulation results determining the distributions of flow velocity and pressure in the individual channels of a plate heat exchanger. The simulations have been conducted by means of the Finite Volume Method (FVM) of numerical computation using the ANSYS CFX software. The computational model constituted spaces_between 10 flat, straight flow type plates of the heat exchanger. The obtained results of numerical simulations confirm the presence of inhomogeneous flow conditions in the neighbouring channels between the plates. The computations enabled to point out the regions on the plates, in which insufficient flow can result in problems with their cleaning. The results of this work constitute the first part of a research leading to an assessment of cleaning conditions in plate heat exchangers.
\end{abstract}

Keywords: PHE, CFD, cleaning in CIP system

\section{INTRODUCTION}

Plate heat exchangers are used in many branches of industry e.g. in ceramic or petrol sectors. They are most widely used in food industry (mainly in dairy, brewing, fruit and vegetable processing, and oil and fat industries) where they play a leading role in processes involving intensive heat exchange. A wide interest in these devices mainly results from their high efficiency, but also from their simple construction and maintenance. The basic elements for their construction are thin, specially formed plates with gaskets whose configuration determines flow direction. Each consecutive plate in an exchanger is turned by $180^{\circ}$ compared to the previous one - thus creating two independent flow channels. In one of them there is a heating/cooling medium and in the other, a product, which undergoes thermal processing (Tsai et al., 2009).

The corrugate geometry plates of heat exchangers and their high temperature working conditions are the reasons why it is difficult to keep them clean and are responsible for maintenance problems. The fouling builds up fast and it is difficult to remove it using standard procedures. It impairs tightness of the exchanger plates and hence is hazardous to safe food production. It is particularly evident in dairy industry during milk pasteurisation. Milk proteins denaturate, coagulate and then adsorb on the surface of the plates causing their contamination. The thickness of the layer and the time at which it builds up depends on protein concentration in the milk layer of higher temperature (near the plate's hot surface) (de Jong et al., 1992; Georgiadis and Macchietto, 2000; Grant et al., 1996). Chen et al. (2004) observed that the milk fouling layers are more compact and adhered strongly on the surface of stainless steel as

\footnotetext{
*Corresponding author, e-mail: joanna.piepiorka@tu.koszalin.pl

${ }^{1}$ Paper presented in an abbreviated form at the International Conference of Agricultural Engineering CIGR-AgEng 2012, July 8-12 2012, Valencia, Spain
} 
temperature of heat treatment is higher. The colour of the fouling deposits become darker, which is probably caused by extensive Maillard reactions. As a result contaminants adhere more strongly to the surface and their removal becomes more problematic. Aggregated deposits negatively influence the heat exchange between flowing media, increase flow resistance and cause corrosion of the plates. Deposits also cause undesirable accumulation of micro-organisms and they may become a source of microbiologic contamination (Diakun, 2013; Gillham et al., 2000; Jun and Puri, 2006; Merheb et al., 2007). They are hazardous to both production hygiene and the entire technological process.

The cleaning of plate heat exchangers is accomplished by CIP stations. The cleaning process does not require disassembling of an exchanger because it is carried out in flow regime. Only the conditions of cleaning need to be selected and controlled. Plate heat exchangers work as parts of closed-loop systems, therefore the effectiveness of their cleaning can be assessed only on the basis of microbiological cultures taken from rinsing solutions. However, it is not known to what degree the plates were cleaned after milk fouling. Milk fouling builds up fast and while unclean is an ideal source of nutrients for micro-organisms. Flow velocity of cleaning solutions is the crucial factor in the final result of the cleaning process (Blel et al., 2007; Diakun, 2011; Grasshoff, 1992; Lelievre et al., 2002a; Lelievre et al., 2003; Jensen et al. 2005). It is expressed as mechanical influence of liquid and local shear stress on the surface of the cleaned elements, which are a function of the flow velocity and the Reynolds number, $R e$. That is why their maximisation ought to be strived for in the process of cleaning (Diakun et al., 2010; Lelievre et al., 2002a). Grasshoff (1992) and Lelievre et al. (2002a) observed that the hydrodynamic conditions of cleaning during the process of cleaning have been influenced not only by physical cleanliness but also by the reductio of micro-organisms. Flowing cleaning solutions moisten and dissolve deposits as well as detach them from the surface and discharge outside the system. The degree of cleanness depends on the accessibility of cleaning solutions to the cleaned surface and their impact on the plates, the latter being closely related to the plate structure. Cleaning in the CIP system does not always result in desirable effects (Austin and Bergeron, 1995; Lelievre et al., $2002 \mathrm{~b}$ ). In order to understand this process better,it should be analysed by taking into consideration flow conditions in the equipment. The variable geometry of plates is a decisive element responsible for flow character and for the degree of plates' cleanness while the geometry of a channel between heat exchanger's plates exerts the influence on the regions with low-velocity of fluid flow (Piepiórka and Diakun, 2011).

This research presents a 3D numerical modelling of the flow in the space between heat exchanger's plates, for a flat geometry plate model.

The aim of this research was to determine flow conditions in parallel channels between plates of a heat exchanger by using a numerical analysis. The research has been the basis for imaging the distribution of pressure, flow's velocity in individual channels.

\section{RESEARCH METHODOLOGY}

Numeric calculations have been carried out by means of the final volume method (FVM), with the use of Ansys CFX 12 software. The calculations have been performed for a heat exchanger assembled into 10 channels of a single medium. The geometrical model has been simplified to a form of flat plates with a flow gap of $0.004 \mathrm{~m}$ between them. The fluid flow in the exchanger was assumed parallel. A regular grid with an element size of $0.001 \mathrm{~m}$ has been applied for discretisation of the computational model. The total number of elements is 1,291,260. Taking into account the aim of the study, physical parameters of medium independent of temperature have been assumed. The fluid flowing through the channels of the analysed system was water of viscosity and density at $T=45^{\circ} \mathrm{C}$. It has also been assumed that the conditions of the flow were stationary. Additionally, it has been presupposed that fluid 
flow is turbulent and that turbulence models comprise the standard definition of the boundary layer description.
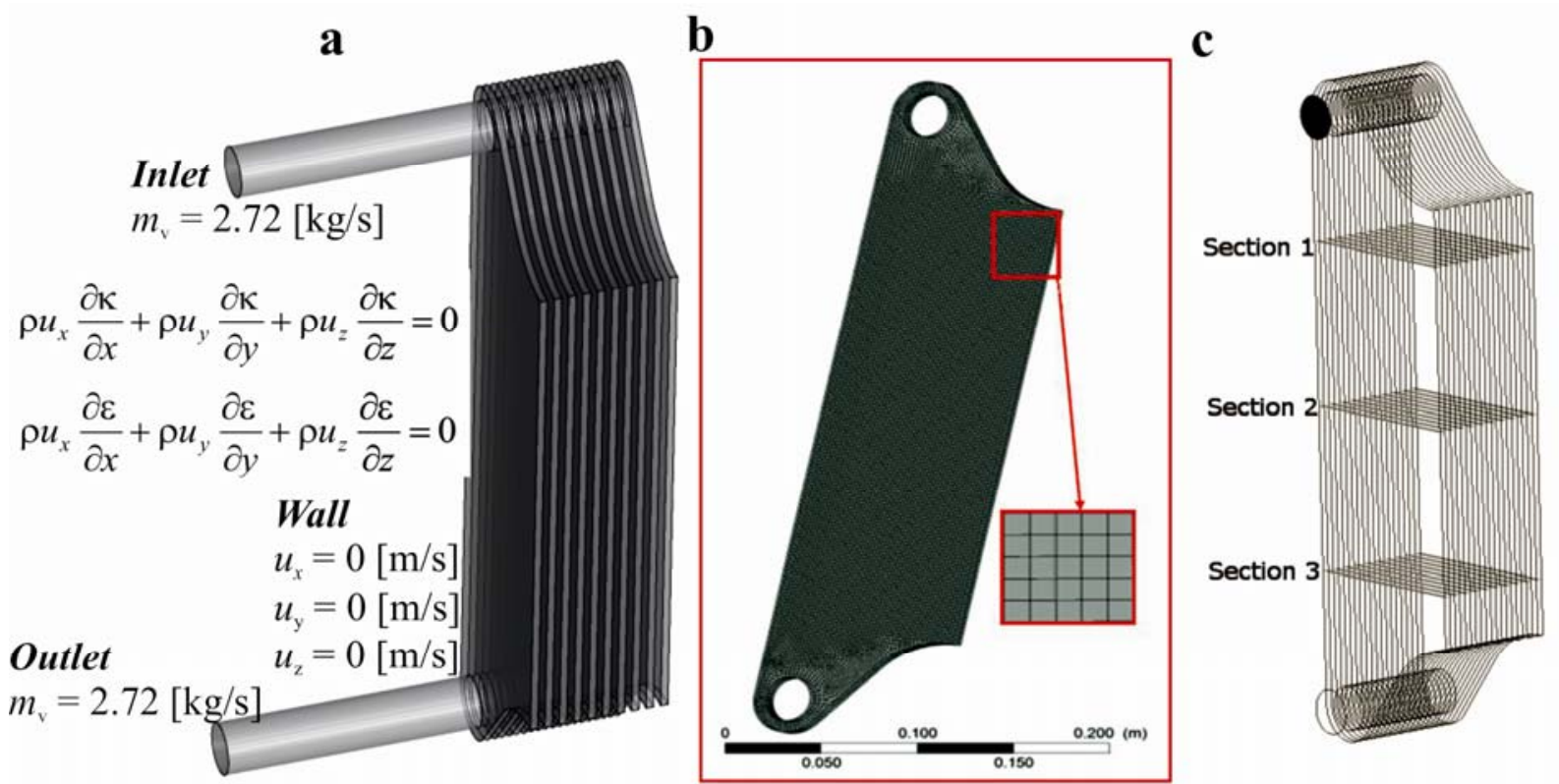

Fig. 1. $a$ - Analysed plate heat exchanger; $b$ - Single channel between two flat plates; $\mathrm{c}-$ Analysed section in plate heat exchanger

A semi-empirical model of turbulence has been applied in the analysis of fluid flow in the gap between the plates of an exchanger: $\kappa-\varepsilon$ (Gryboś 1989; Kazimierski 2004; Luan et al. 2008). The boundary conditions have been used for calculations resulting from the influence of the plates forming a flow gap for the fluid by assuming zero velocity values on the plates' surface and edges, and zero values of the kinetic energy and dissipation of turbulence in the first iteration (Fig. 1). The computations have been carried out for a constant mass flow rate equal to $m_{v}=2.72 \mathrm{~kg} / \mathrm{s}$ assumed at the inlet and outlet of the exchanger. The initial conditions applied in the estimation of the computational average of the flow velocity between the plates corresponded to $u_{c h}=0.55 \mathrm{~m} / \mathrm{s}$ and the Reynolds number of $R e=8187$, which proves the turbulent character of the flow.

The computational model was split into three areas (Fig. 2): the upper part (section 1), the central portion (section 2) and the lower part (section 3).

\section{RESULTS OF COMPUTATION AND ANALYSIS}

Figure 2 presents results of velocity streamlines for parallel medium streams of a heat exchanger. It has been stated that the highest flow velocity is to be found in the first flow channels located closest to the inlet area. The flow velocities decrease in the channels distant from the first plates, and the lowest flow velocity is measured in the last channel of the exchanger.

Numerical results of the flow distribution in a neighbouring flat, narrow-gap are different. In individual channels the highest flow velocity has been observed in the inlet to the gaps and on their outlet. In the central parts of the plate the flow velocity amounts to $0.6 \mathrm{~m} / \mathrm{s}$. However, there is flow velocity close to $0 \mathrm{~m} / \mathrm{s}$ in the top right and the bottom right corners of the plates. It might suggest the risk of flow stagnation conditions in these areas. Furthermore, it has been noticed that the farther from the inlet of fluid, the flow velocity is slower. The streamline results revealed that there are no flow disturbances (Fig. 2). In each analysed channel, fluid flowing through the inlets is mostly directed towards outer 
edges. At these points the flow velocity is the highest. The lowest concentration of the streamlines occurs in central parts of the first channels. It results in low-velocity fluid flow in these regions. As the plates distance themselves from the inlet port, the streamlines arrange parallelly moving towards the outlet port.

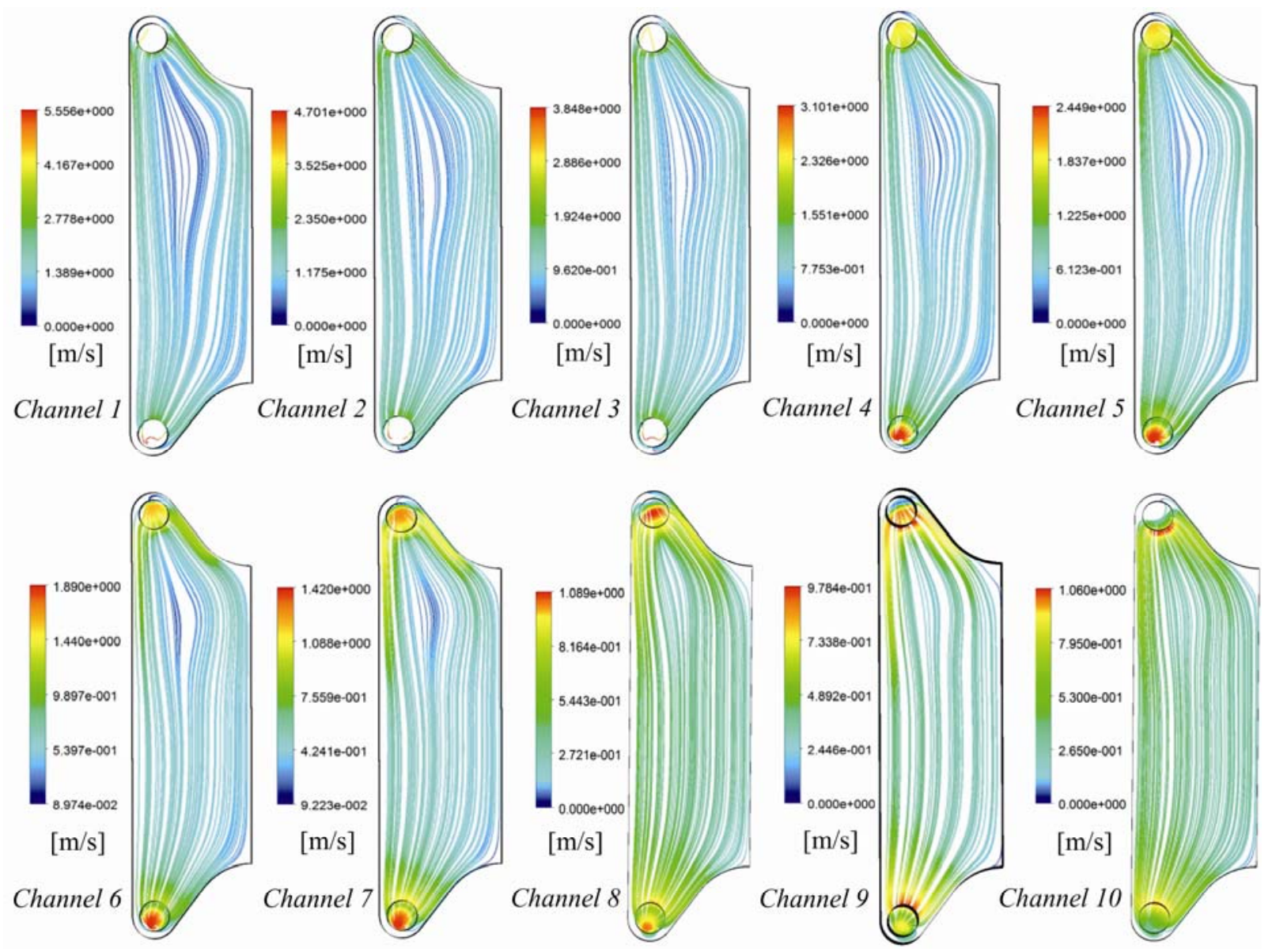

Fig. 2. Streamlines of velocity for parallel medium streams of a heat exchanger

The results of the flow velocity simulations obtained for three regions of the plate heat exchanger: at the top, in the middle and at the bottom, are shown as a distribution of velocity fields and profiles of flow velocity (Fig. 3). The flow velocity differs spatially and longitudinally in the three analysed regions.

At the top of the plates (cross-section 1) the highest flow velocity is on the outer edges. At the first plates on their left side the local velocity is within the range of $1.85 \mathrm{~m} / \mathrm{s}$ but on their right side is within the range of $1.65 \mathrm{~m} / \mathrm{s}$. The lowest flow velocity over the range of $0.2 \div 0.5 \mathrm{~m} / \mathrm{s}$ exists at the axis symmetry of plates. At the cross-section 2 the flow velocities are over the range of $0.4 \div 0.7 \mathrm{~m} / \mathrm{s}$. The highest values of flow velocity exist on their outer edges and they are $1.75 \mathrm{~m} / \mathrm{s}$ on the left side of the plates and $1.25 \mathrm{~m} / \mathrm{s}$ on the right side of the plates. At the cross-section 3, the flow velocity stabilises in the range $0.3 \div 1.5 \mathrm{~m} / \mathrm{s}$. On the right edge of the plates a rapid drop in flow velocity occurs. It may cause difficulties in cleaning these regions of plates in heat exchangers.

The analysis of velocity distribution in relation to the effectiveness of cleaning suggests that the best cleaned regions on a single plate are those of high flow velocity, and the worst cleaned ones are the regions with lower flow velocity. The regions with low fluid velocity could be also the most contaminated areas in plate heat exchangers. $\beta$-LG denaturation (i.e. thermal damage) is initiated in the regions where fluid is slowed down and the contact time with heating surfaces is longer (de Bonis and Ruocco, 2009). This exacerbates the problem. The obtained results of numerical simulations confirm 
that application of plates with corrugated surface at heat exchangers is important. The corrugated profile of a thermal plate and fluid flow rate affect a turbulent fluid flow and mixing intensity (de Bonis and Ruocco 2009; Grijspeerdt et al. 2003). High turbulence in the PHE leads to: enhanced heat transfer, low fouling rate, and reduced heat transfer area.
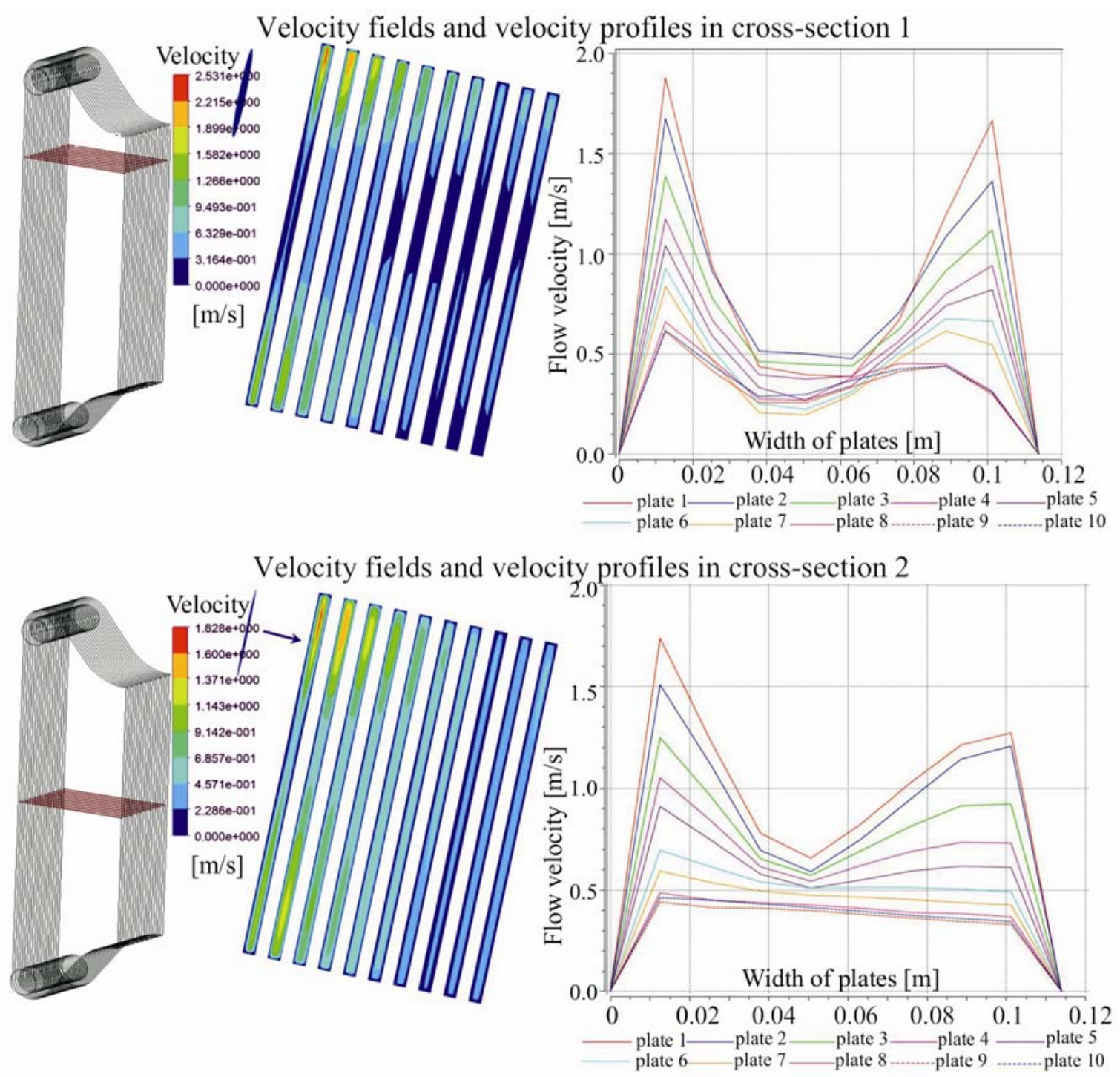

Velocity fields and velocity profiles in cross-section 3

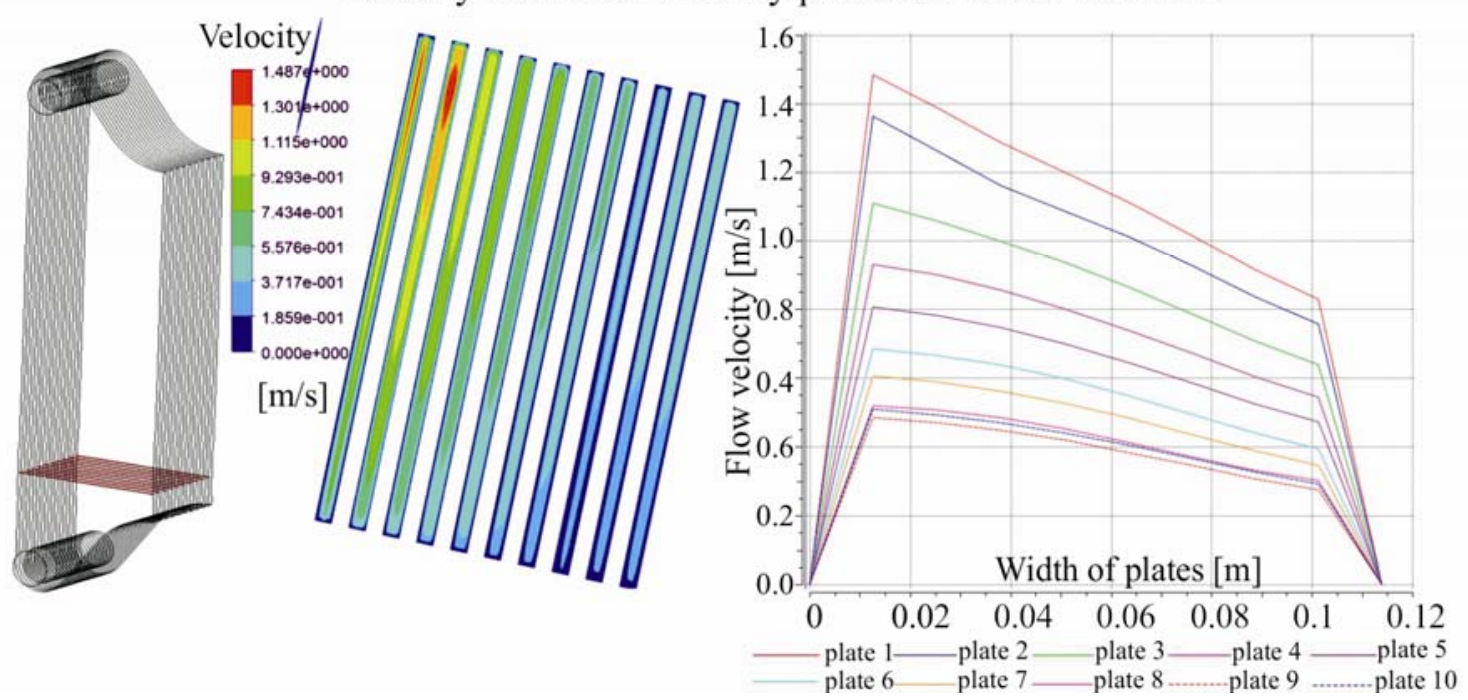

Fig. 3. Distribution of velocity fields and profiles in analysed regions 
The results of numerical calculations of pressure distribution fields for each analysed regionand the curves of pressure distribution are presented in Figure 4.

Pressure fields and pressure profiles in cross-section 1

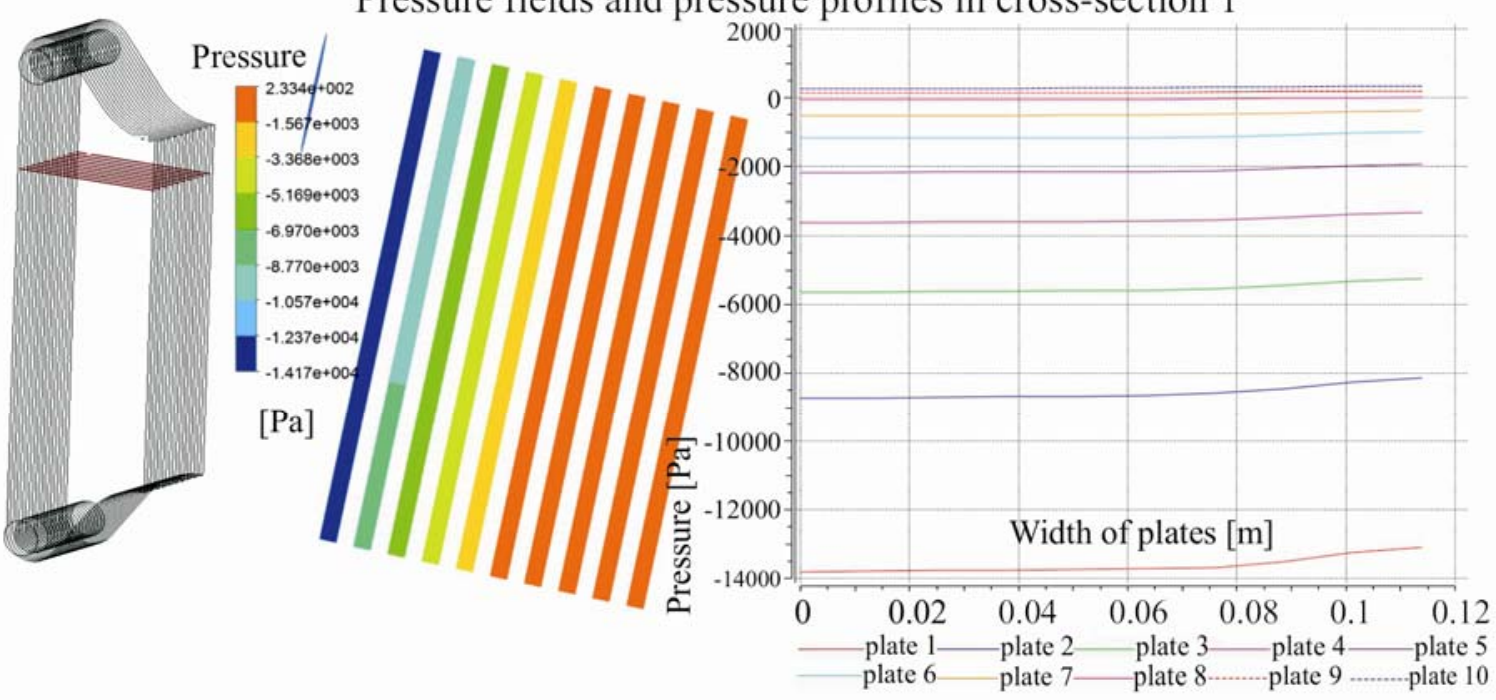

Pressure fields and pressure profiles in cross-section 2

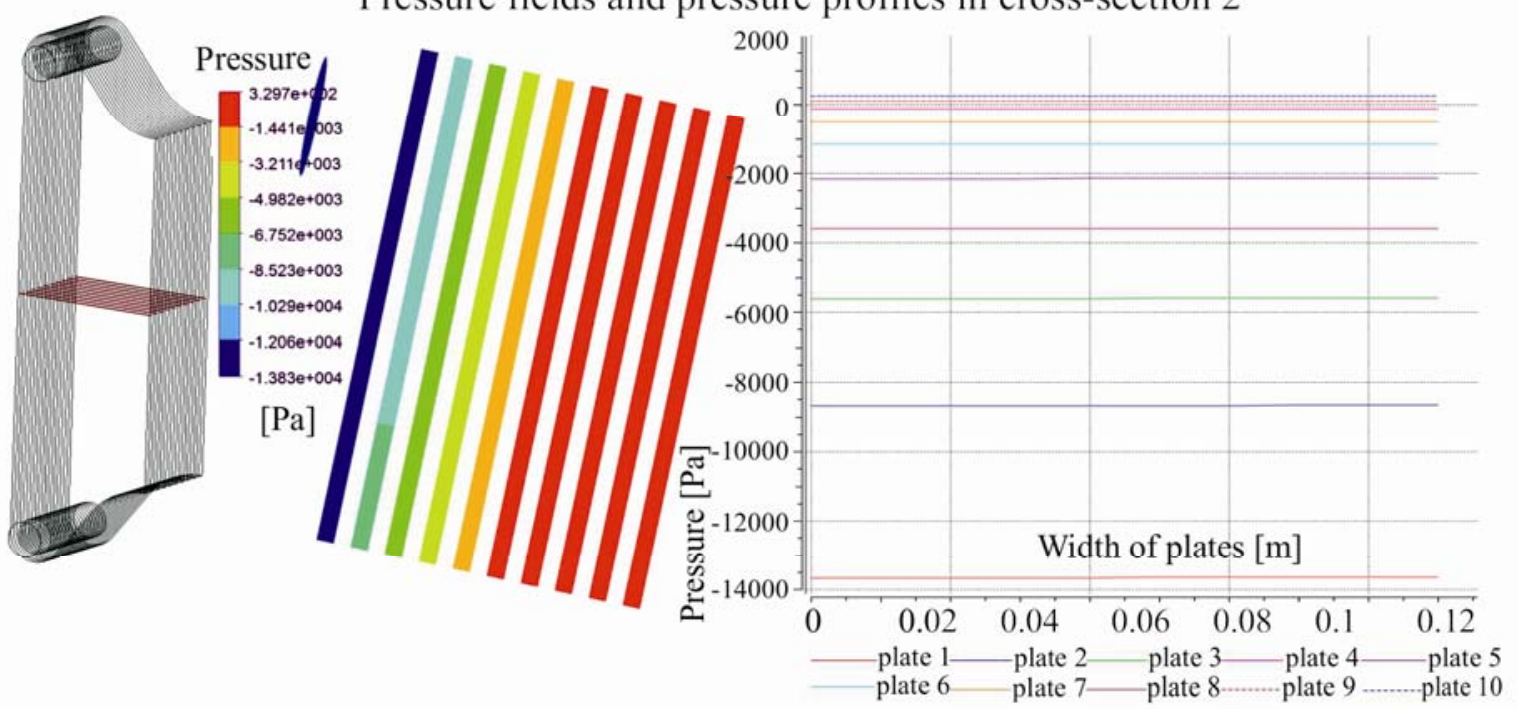

Pressure fields and pressure profiles in cross-section 3

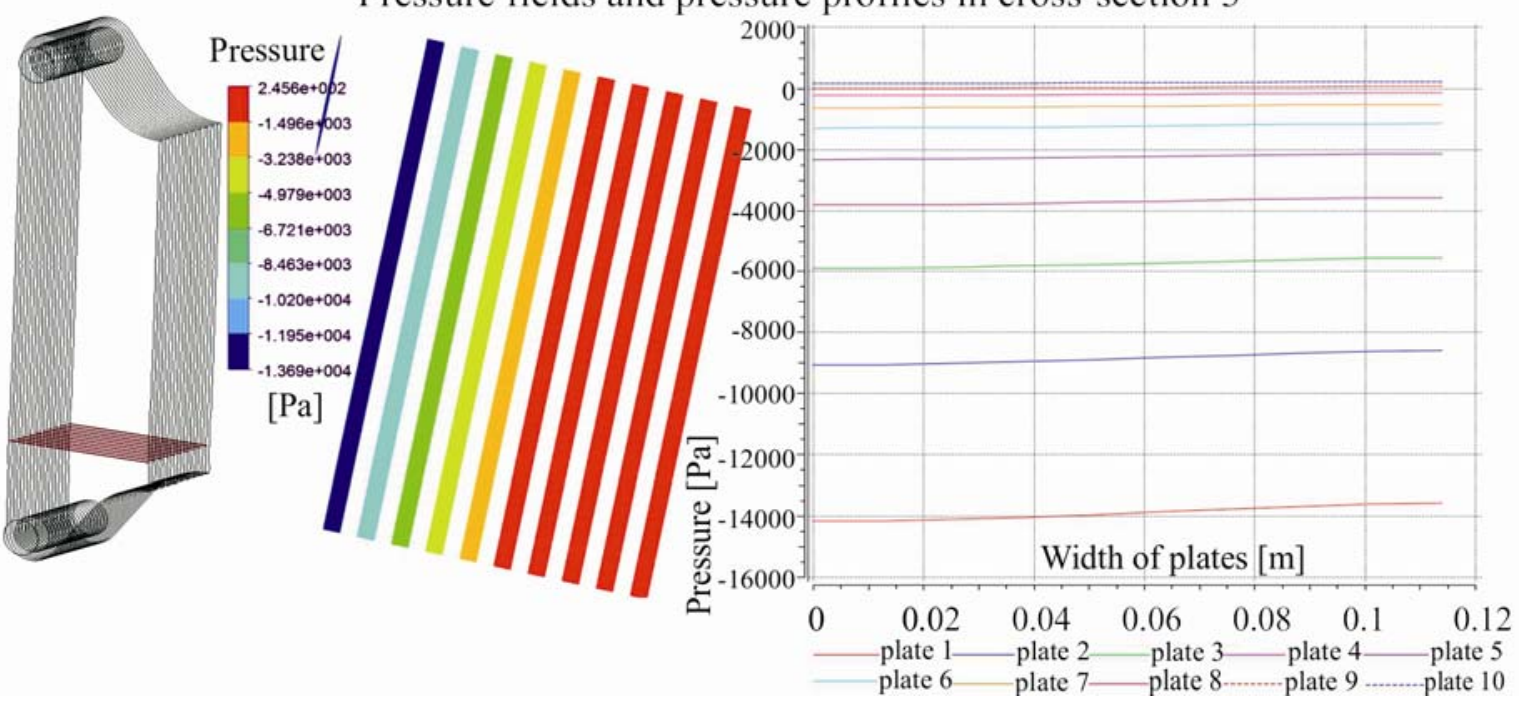

Fig. 4. Distribution of pressure fields and profiles in analysed regions 
Pressure distribution in this model indicates that the highest values occur in the of a channel between the plates outermost from the supply areas. The pressure of fluid flow in the space between the plates of a heat exchanger should be interpreted as a relative pressure related to a reference pressure, which was set at $101325 \mathrm{~Pa}$. This means that the values on the scale correspond to the increase in relation to the reference pressure.

\section{CONCLUSIONS}

- CFD calculations allowed to obtain information on distribution of flow velocity in different regions of the model of the plate heat exchanger. The application of a simplified flat plate model, though it does't fully correspond to the actual flow conditions in the exchangers, but shows that in some individual regions of heat exchanger low-velocity fluid flow is possible.

- Different flow velocity in the neighbouring channels between the plates of a heat exchanger may not only cause inhomogeneous conditions for cleaning in the CIP system, but can also affect the thermal treatment of the product. Furthermore, in the areas with a low-velocity product flow prolonged exposure of product to thermal treatment is possible. Thus, deposit build-up may be enhanced in these regions.

- From the obtained fluid flow characteristics one could conclude that great diversification of flow velocity and pressure in exchangers with flat plates is possible. The highest flow velocities are developed at the plates' edges and at the outlet of an exchanger while the lowest ones occur in the plate's axis of symmetry, and in its top right corner located opposite the outlet.

Research financed in 2010-2011 by the Polish Ministry of Science and Higher Education within research project No. $N$ N313 136838 .

\section{SYMBOLS}

$\begin{array}{ll}m_{v} & \text { mass flow rate, } \mathrm{kg} / \mathrm{s} \\ u_{c h} & \text { flow velocity between the plates, } \mathrm{m} / \mathrm{s} \\ R e & \text { Reynolds number } \\ T & \text { temperature, }{ }^{\circ} \mathrm{C} \\ x, y, z & \text { Cartesian coordinates }\end{array}$

Greek symbols

$\varepsilon \quad$ energy dissipation rate, $\mathrm{m}^{2} / \mathrm{s}^{3}$

$\kappa \quad$ kinetic energy, $\mathrm{m}^{2} / \mathrm{s}^{2}$

\section{REFERENCES}

Austin J.W., Bergeron G., 1995. Development of bacterial biofilms in dairy processing plants. J. Dairy Res., 62, 509-519. DOI: $10.1017 / \mathrm{S} 0022029900031204$.

Blel W., Benezech T., Legentilhomme P., Legrand J., Le Gentil-Lelievre C., 2007. Effect of flow arrangement on the removal of Bacillus spores from stainless steel equipment surfaces during a Cleaning In Place procedure. Chem. Eng. Sci., 62, 3798-3808. DOI: 10.1016/j.ces.2007.04.011.

Chen X. D., Li D. X.Y., Lin S. X.Q., Özkan N., 2004. On-line fouling/cleaning detection by measuring electric resistance - equipment development and application to milk fouling detection and chemical cleaning monitoring. J. Food Eng., 61, 181-189. DOI:10.1016/S0260-8774(03)00085-2. 
de Bonis M.V., Ruocco G., 2009. Conjugate fluid flow and kinetics modeling for heat exchanger fouling simulation. Int. J. Therm. Sci., 48, 2006-2012. DOI: 10.1016/j.ijthermalsci.2009.03.010.

de Jong P., Bouman S., van der Linden H.J.L.J., 1992. Fouling of heat transfer equipment in relation to the denaturation of $\beta$-lactoglobulin. J. Soc. Dairy Technol., 45, 3-8. DOI: 10.1111/j.1471-0307.1992.tb01715.x.

Diakun J., 2011. Impact analysis for individual factors in the process of system and equipment washing. Agricultural Eng., 1, 23-29 (in Polish).

Diakun J., 2013. Review, scheme and cleaning methods analysis. Polish J. Food Eng., 1/4 , 5-10.

Diakun J., Piepiórka J., Bil T., 2010. Polioptymalizations cleaning condition of cleaning pipelines. Problem Papers Progress of Agricultural Sciences, 546, 69-76.

Georgiadis M.C., Macchietto S., 2000. Dynamic modeling and simulation of plate heat exchangers under milk fouling. Chem. Eng. Sci., 55, 1605-1619. DOI: 10.1016/S0009-2509(99)00429-7.

Gillham C.R., Fryer P.J., Hasting A.P.M., Wilson D.I., 2000. Enhanced cleaning of whey protein soils using. pulsed flows. J. Food Eng., 46, 199-209. DOI: 10.1016/S0260-8774(00)00083-2.

Grant C.S., Webb G.E., Jeon Y.W., 1996. Calcium phosphate decontamination of stainless steel surfaces. $A I C h E$ J., 42, 861-875. DOI: 10.1002/aic.690420324.

Grasshoff A., 1992. Hygienic design: The basis for computer controlled automation. Food and Bioprod. Process., Trans. IChemE, Part C, 70, 69-77.

Grijspeerdt K., Hazarika B., Vucinic D., 2003. Application of computational fluid dynamics to model the hydrodynamics of plate heat exchangers for milk processing. J. Food Eng. $\overline{57,237}-242$. DOI: 10.1016/S02608774(02)00303-5.

Gryboś R., 1989. Basic mechanics of liquids. PWN, Warsaw (in Polish).

Jensen B.B.B., Friis A., Bénézech T., Legentilhomme P., Leličvre C., 2005. Local wall shear stress variations predicted by computational fluid dynamics for hygienic design. Food and Bioprod. Process., 83, 53-60. DOI: 10.1205/fbp.04021.

Jun S., Puri V.M., 2006. A 2D dynamic model for fouling performance of plate heat exchangers. J. Food Eng., 75, 364-374. DOI:10.1016/j.jfoodeng.2005.03.064.

Kazimierski Z., 2004. Podstawy mechaniki płynów i metod komputerowej symulacji przepływów. 1st edition. Lodz University of Technology, Lodz, 178 - 186; 197 - 207. ISBN 8372831335.

Lelievre C., Legentilhomme P., Gaucher C., Legrand J., Faille, C., Bénézech, T., 2002a. Cleaning in place: effect of local wall shear stress variation on bacterial removal from stainless steel equipment. Chem. Eng. Sci., 57, 1287-1297. DOI: 10.1016/S0009-2509(02)00019-2.

Lelievre, C., Antonini, G., Faille, C., Bénézech, T., 2002b. Cleaning-in-place, modelling of cleaning kinetics of pipes soiled by Bacillus spores assuming a process combining removal and deposition. Food and Bioprod. Process. 80, 305-311. DOI: 10.1205/096030802321154826.

Lelievre, C., Legentilhomme, P., Legrand, J., Faille, C., Bénézech, T., 2003. Hygienic design: Influence of the local wall shear stress variations on the cleanability of a three-way valve. Chem. Eng. Res. Des., 81, $1071-1076$. DOI: $10.1205 / 026387603770866209$.

Luan Z. J., Zhang G. M., Tian M. C., Fan M. X., 2008. Flow resistance and heat transfer characteristics of a newtype Plate Heat Exchanger. J. Hydrodynam., 20, 524-529. DOI: 10.1016/S1001-6058(08)60089-X.

Merheb B., Nassar G., Nongaillard B., Delaplace G., Leuliet J.C. 2007. Design and performance of a lowfrequency non-intrusive acoustic technigue for monitoring fouling in plate heat exchangers. J. Food Eng., 82 , 518-527. DOI:10.1016/j.jfoodeng.2007.03.022.

Piepiórka J., Diakun J., 2011. Uneven surface cleaning of heat exchanger plates. Chemical Engineering and Equipment, 50, 1, 33-34 (in Polish).

Tsai Y.C., Liu F.B., Shen P.T., 2009. Investigations of the pressure drop and flow distribution in a chevron-type plate heat exchanger. Int. Commun. Heat Mass Transf., 36, 574-578. DOI: 10.1016/j.icheatmasstransfer.2009.03.013.

Received 15 January 2013

Received in revised form 28 October 2013

Accepted 04 November 2013 